\title{
Phenotypic component parameters in cowpea for Bastar Plateau Agroecological conditions
}

\author{
Sunita Singh and Prafull Kumar
}

Article Chronicle : Received: 02.03.2020;

Revised :

08.05.2020;

Accepted :

24.05.2020

Key Words :

Leaf area,

Correlation,

Linkage, Cowpea
ABSTRACT : A field experiment was conducted during Kharif 2016-17 to estimate the phenotypic component parameters for twelve quantitative characters among 23 genotypes. Hundred seed weight showed significant positive correlation with leaf length $(0.2723 * *)$, peduncle length $(0.2649 * *)$, plant height $\left(0.3623^{* *}\right)$, pod length $\left(0.2419^{* *}\right)$, days to $1^{\text {st }}$ flowering $\left(0.3413^{* *}\right)$, days to 50 per cent flowering $(0.3608 * *)$ and green pod yield per plant $\left(0.6110^{* *}\right)$. On the other side, hundred seed weight showed significant negative phenotypic correlation with number of pod per plant $\left(-0.2319^{* *}\right)$, number of primary branches $\left(-0.3658^{* *}\right)$ and number of cluster per plant $\left(-0.2946^{* *}\right)$. The green pod yield per plant exhibited highly significant positive association with leaf length $\left(0.2596^{* *}\right)$, leaf width $\left(0.3208^{* *}\right)$, plant height $\left(0.3357^{* *}\right), 100$ seed weight $\left(0.6110^{* *}\right)$, days to $1^{\text {st }}$ flowering $\left(0.4082^{* *}\right)$ and days to 50 per cent flowering $(0.4380 * *)$ but not correlated negatively with any characters. High correlation of green pod yield per plant with plant height, 100 seed weight, first flowering and 50 per cent flowering suggested that green pod yield could be raised by selecting for early maturing plant type having sufficient crop canopy. However, when crop is grown as leguminous fodder and green manuring purpose, breeding should be practiced for comparative higher canopy with higher crop growth rate and late maturing genotypes should be preferred.

HOW TO CITE THIS ARTICLE : Singh, Sunita and Kumar, Prafull (2020). Phenotypic component parameters in cowpea for Bastar Plateau Agroecological conditions. Asian J. Environ. Sci., 15(1): 13-18, DOI: 10.15740/ HAS/AJES/15.1/13-18. Copyright@ 2020: Hind Agri-Horticultural Society.
Author for correspondence :

Prafull Kumar S.G. College of Agriculture and Research Station (I.G.K.V.), Jagdalpur (C.G.) India Email : prafull397@ gmail.com

See end of the article for Coopted authors' 